\title{
ALASAN SAYA MENJADI GURU SD
}

\section{Putri Dewi Syatiti}

Universitas Nahdlatul Ulama Sidoarjo

Email: Syatiti27@gmail.com

Guru merupakan jembatan ilmu, anak belajar itu tidak harus ada yang mendampingi, semua orang dapat belajar dimanapun tempat, semua tempat bisa dijadikan untuk belajar. Akan tetapi, seorang anak terutama ditingkat SD masih membutuhkan pendamping atau guru supaya anak tersebut bisa terkendalikan arahnya (Saputra, 2012). Dalam Kamus Besar Bahasa Indonesia"Guru adalah orang yang pekerjaannya atau profesinya sebagai mengajar"(Kbbi, 2018).

Pendidikan adalah suatu kegiatan pembentukan kesadaran dan kepribadian anak didik di samping transfer ilmu dan keahlian (Qori'ah et al., 2017). Setiap manusia yang memiliki ilmu selayaknya harus mengamalkan ilmu tersebut (Asitah et al., 2017). Pendidikan Indonesia membutuhkan peningkatan akses, mutu dan relevansi pendidikan untuk memberi manfaat membangun bagi pendidikan dan rakyat Indonesia (Irawan et al., 2018). Siswa perlu memahami apa yang diketahui dan apa yang diminta untuk memiliki kemampuan menjawab (Suci et al., 2018). 
Sehingga, sebagai guru privat yang baik kita harus luwes kepada peserta didik yang kita privati.

Privat merupakan mengajar yang fokus pada satu anak. Sebagai guru privat haru mempunyai kemampuan berkomunikasi dengan baik kepada peserta didiknya serta teknik pengajarannya harus kreatif agar peserta didik lebih semangat dalam belajar. Sebagia guru privat harus lebih menguasai materi yang akan diajarkan dan lebih mempersiapkan diri lebih matang sebelum mengajarkan kepada peserta didik. Senantiasa harus selalu berpegang teguh pada sifat yang dimiliki oleh Rasul yaitu jujur, amanah, fathana, siddiq selain itu juga harus bermodal ikhas, karena Allah ingin agamanya itu di amalkan, poin yang kedua yaitu do'a para alim dan ulama terdahulu lah yang sangat penting dan point yang ke tiga yaitu transparan kepada semua orang agar sesuatu yang di kerjakan mendapat kepercayaan dari orang lain (Munjidah, et al., 2017).

Pemimpin harus seperti IImu Nahwu dalam Bahasa Arab yaitu harus bisa Marfu' (dhummah) dan Manshub (fathah), jangan seperti Majur dan Majzum. Marfu' yang berarti memeluk atau merangkul, sedangkan Manshub yang berarti terbuka tanpa ada yang ditutupi. Jangan seperti Majrur yang berarti menginjak-injak atau merendahkan orang lain. Seperti kata orang dahulu, yaitu Ngeluruk Tanpo Bolo, Menang Tanpo 
Ngasorake, Sakti Tanpo Aji-Aji, Sugeh Tanpo Bolo (Maula et al., 2017).

Mengenali latar belakang murid yang diprivati itu sangat penting bagi guru privat, dikarenakan berbagai macam siswa yang akan dihadapi. Ada yang pendiam, cerewet, aktif, dll. Jangan menjadi guru privat yang garang atau jahat. Buatlah didalam pembelajaran tersebut sedikit humor tapi tidak berlebihan, agar otak siswa tersebut tidak tegang dan merasa bosan. Akan tetapi jangan terlalu humor maka akan menjadikan anak tersebut tidak fokus pada mata pelajaran. Apabila anak tersebut mempunyai keunggulan pada dirinya maka sikap yang baik sebagain guru privat seharusnya memberi apresiai seperti memberi pujian, ataupun hadiah secukupnya (pensil, bulpoint, dll). Sebagai guru privat sebaiknya harus tulus dalam mengajar, jangan mengharapkan imbalan yang lebih agar ilmu yang diajarakan menjadi barokah dan manfaat.

Sebagian besar mahasiswa lulusan UNUSIDA rata-rata yang jurusan PGSD semuanya menjadi guru SD, dan itu akan menjadi kebanggaan tersendiri bagi UNUSIDA. Menjadi seorang guru bisa dibilang susah juga bisa dibilang mudah, apabila guru tersebut tidak bisa menguasai kelas dengan baik maka siswa pun akan menjadi bosan.

Kompetensi seorang guru sangat menunjang akan keberhasilan dalam proses pembelajaran. Guru yang memiliki kompetensi yang baik akan 
mampu menciptakan suasana kelas yang aktif, kreatif, efektif, dan menyenangkan (Hamalik, 2002).

Kompetensi yang dimiliki seorang guru akan menunjukkan bahwa guru tersebut mempunyai kualitas dala mengajar dengan baik. Apabila ingin menjadi guru SD maka pendidikan yang ditempuh adalah jurusan PGSD, agar tidak melenceng dari apa yang diharapkan. Empat tahun menempuh kuliah jurusan PGSD tidaklah mudah, banyak rintangan yang akan dihadapi. Apabila melakukannya dengan ikhlas dan jujur maka hasil yang didapat pun akan baik dan sesuhai yang diharapkan.

\section{Grafik 1. Distribusi Frekuensi Guru SD Berdasarkan Kategori Guru Kelas dan Kepala Sekolah}

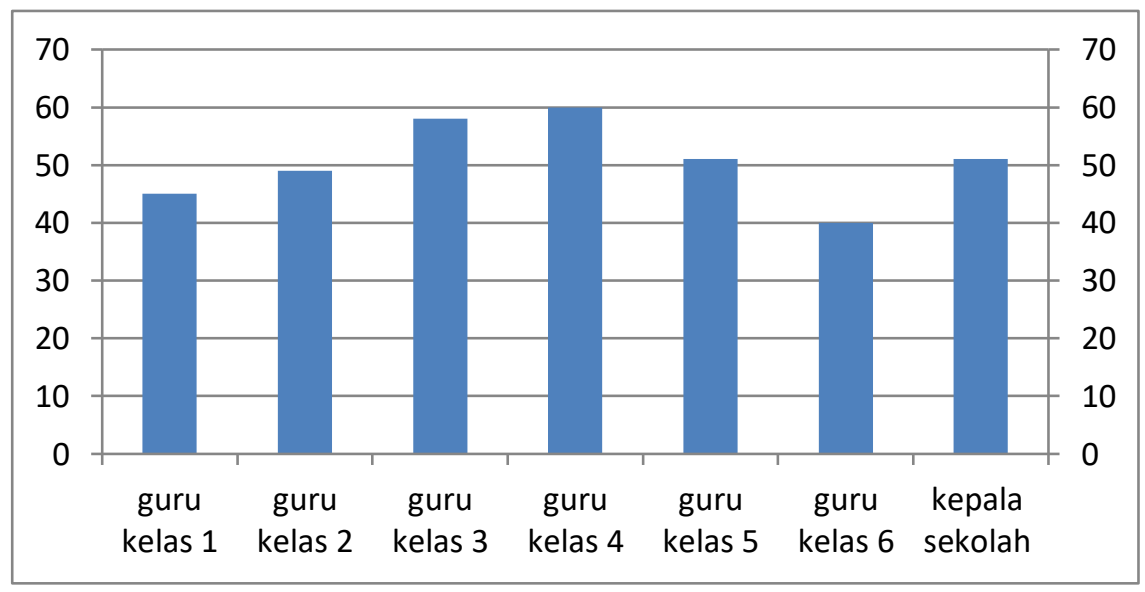


Grafik 2. Distribusi Frekuensi Guru SD Berdasarkan Jenjang pendidikan

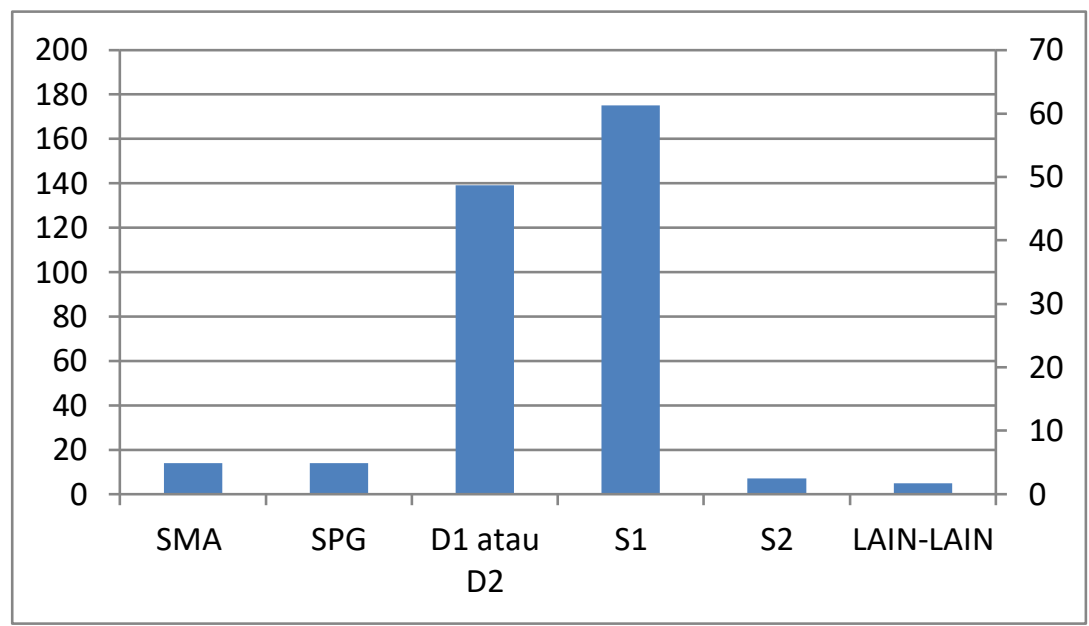

Grafik 3. Distribusi Frekuensi Guru SD Berdasarkan Kategori Lama Mengajar 


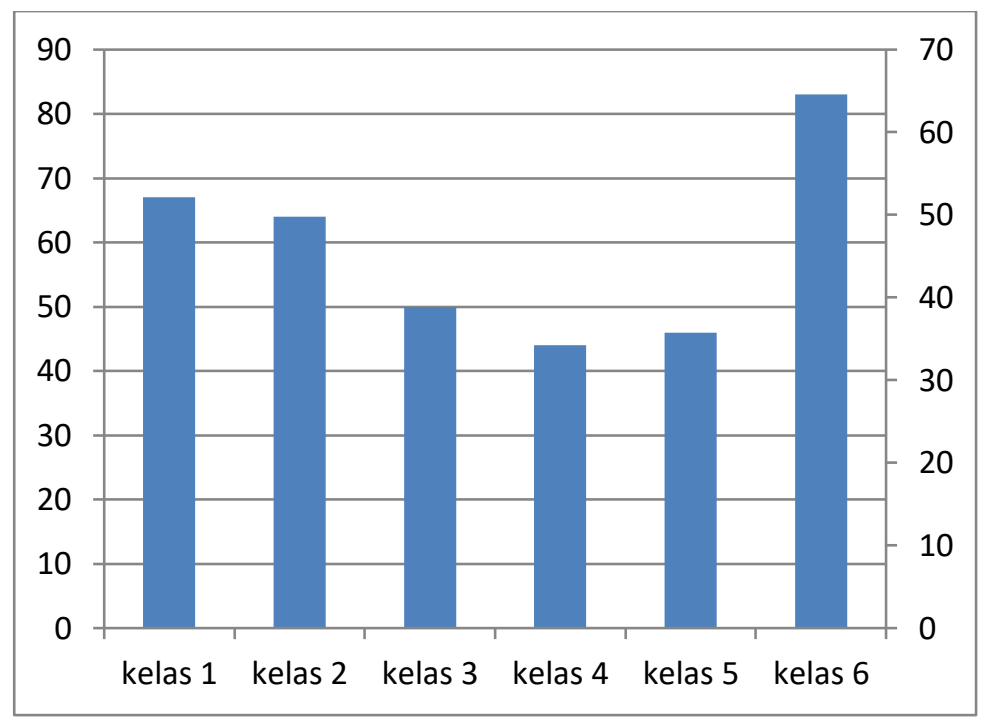

\section{Kesimpulan}

Memperhatikan peran seorang guru dan tugas seorang guru sebagai salah satu faktor yang mendorong akan keberhasilan peserta didik, maka peran guru sangat penting bagi dunia pendidikan. Menjadi guru SD tidaklah mudah, banyak guru SD yang mengeluh akan kenakalan peserta didiknya. Akan tetapi, guru yang ikhlas mentransferkan ilmunya akan lebih nyaman dalam mengajarkan kepada peserta didiknya. Menjadi guru SD harus mengerti keadaan peserta didiknya. Harus bisa menciptkan suasana yang menyenangkan agar proses belajar mengajar menjadi lebih nyaman. 


\section{References}

Asitah, N., Maula, I., Munjidah, A., Nahdiyah, K., Yuniarti, D., Sholichah, S. A., Purnomo, A., Rosyidah, E., Anam, Fatkul., Achmadi, A.A., Fahmi, M. (2018, May 25). Urgensi Aktualisasi Manajemen Sumber Daya Manusia untuk Resurgensi Perekonomian di Sidoarjo. http://doi.org/10.17605/OSF.IO/TG79P

Hamalik. (2002). pendidikan guru. (P. B. Aksara, Ed.). jakarta.

Irawan, D. E., Purnomo, A., Sutiksno, D. U., Abraham, J., Alamsyah, A., Saputra, D. H., Javandira, C., \& Rosyidah, E. (2018). Kajian Pendidikan Tinggi IDRI untuk DPR RI dan Ristek Dikti 2018. Bandung: ITB Press.

KBBI. (2018). dalam kamus besar. Retrieved from http://kbbi.web.id/guru.html.2018/03/27

Maula, I., Yuniarti, D., Mufidah, F.I., Kautsari, M.F., Sholichah, F., Lestari, Y.D., Lailiyah, R., Almardliyah, A., Munadzifah, S., Abadiyah, S., Laili, N.I., Rosyidah, E., Habiburrohman, M., Purnomo, A. (2017). MI Hasyim Asy'ari IImu Harus Terus Mengarus. In Wirausaha Pendidikan Indonesia (Jilid 1). Sidoarjo: Unusida Press.

Munjidah, A., Jhannah, I. P. N., Fidiana, W., Istiana, Z., Fajar, A. A., Kurniawati, D., Alfiati, N., 
Latifah, A. S., Akhladah, A., Willian, A. D., Ainun, A., Fariha, A. N. (2017). MI Thoriqussalam Berpegang Kepada Rosul. In Wirausaha Pendidikan Indonesia (Jilid 4). Sidoarjo: Unusida Press.

Qori'ah, S., Sholikhah, S.A., Fitriyah, N., Jannah, D.F., Sholichah, S.A., Istiqomah, A., Wijayanti, A.N., Mubarokah, L., Rosyidah, E., Mauliddiyah, A.T., Fauziah, L., Ahmadi, C.N.A., Muid, M., Purnomo, A. (2017). MI Hasyim Asy'ari IImu Harus Terus Mengarus. In Wirausaha Pendidikan Indonesia (Jilid 3). Sidoarjo: Unusida Press

Saputra, W. heni. (2012). guru merupakan jembatan ilmu. from

http://wisnuhenisaputra.wordpress.com/2012/1 2/21/artikel

Suci, S. H. A., Rosyidah, E., Asitah, N., Aini, N., Murni, A. W., Anam, F., Purnomo, A., Sallu, S., Mulyaningsih, I., \& Kuraesin, A. D. (2018). Learning from Picture and Picture Action Research: Enhancement of Counting Ability on Division of Numbers for Primary School Students. Journal of Physics: Conference Series, 1114 , 012044. https://doi.org/10.1088/17426596/1114/1/012044 